\title{
Opinions of Prospective Classroom Teachers about Their Competence for Individualized Education Program (IEP)
}

\author{
Murat Debbăg \\ Distance Education Application and Research Center, Bartin University, Turkey
}

Copyright $\subset 2017$ by authors, all rights reserved. Authors agree that this article remains permanently open access under the terms of the Creative Commons Attribution License 4.0 International License

\begin{abstract}
This research aims to determine the opinions of prospective classroom teachers about preparation and implementation of Individualized Education Program (IEP). In this study, a qualitative research method was used. The participants were 20 classroom-teaching students that had been selected through the purposive sampling method. In the study, the questionnaire "Examining IEP" was used as a reference, which has been improved by the researcher. The questionnaire includes open-ended questions. According to the analysis results, prospective class teachers state that they do not think that they are qualified enough to evaluate students' performance, to identify individual needs which is related to the performance, to set or create goals, to collaborate with parents and school administration, or to plan educational adaptations. They also state that they have concerns about possible problems that may arise during implementation of individualized education programs.
\end{abstract}

Keywords Individualized Education Program, Inclusive Education, Prospective Classroom Teacher

\section{Introduction}

Every child has different learning skills and different learning speeds effective for different aspects of learning. In cases where such difference are deeper and more significant, common educational services fail to satisfy and special educational services are needed (Cavkaytar, 2013) [3]. Special education is a combination of educational services that are planned individually aiming to maximize the individual's probability to live independently and it is offered to students who demonstrate cognitive, behavioral, social-emotional, physical or emotional inadequacy (Diken, 2013) [7]. It is essential to have individualized education given in general education classes. We can say that education and training applications disregarding individual differences are not successful. For this reason, we need much more creative and functional, individualized, and long-term education programs in special training, so every single student can benefit from this education depending on his/her weaknesses and strengths (Ozgur, 2001) [22]. In addition, there are a number of problems came across by inclusive students. Besides, there is a huge gap between the education that these students need and how well these needs are met (Gursel, 2007) [11]. Therefore, we have to prepare an "Individualized Education Program" (IEP) for those who cannot benefit from the existing education opportunities because of their disability and for those whose grades are badly influenced by this inequality. While Lytle and Bordin (2001) [18] describe IEP as a program of collaboration involving college personnel, parents and people who provide support services; Fiscus and Mandell (2002) [8] describe this program as a special education program developed by a regional educational institution for children with special needs. Special educational support services are divided into three classes, namely special education counselling, cooperative teaching and resource room teaching (Conoley and Conoley, 2010) [5]. It is stated that cooperative teaching is a way to support both students with special means or normal developmental characteristics and classroom teachers and that it means teachers of general and special education working together by sharing their responsibilities for planning, applying and evaluating the teaching process (Friend and Cook, 2003) [9].

\subsection{Development of an Individualized Education Program}

An IEP covers the student's current education performance, long-term purposes in addition to short-term purposes, special training services that can be provided for the child, the attendance status of the child (i.e. whether he attends a normal education program substantially or not), the exact time to start this kind of services and duration of this period, the suitable purpose, criteria, evaluation phase and a schedule that gives at least one year to evaluate whether the teaching purposes are achieved (Gursel, 2007) [11]. Within the context of these items, an IEP is set by a team for each student identified as inclusive. This team has such members like the headmaster or deputy head of school, school 
counselor, class master, special education teachers, branch teachers, student and their parents, and teachers as observers (MEB, 2010) [19]. Even if special education teachers are considered to be the most knowledgeable members about mainstreaming and IEP in a team and there is a great number of special education teachers in Turkey, if we look at the studies in the literature conducted in Turkey, it is revealed that there is no room for IEP in some schools (Cuhadar, 2006) [6]. Class masters and guidance counselors see IEP as a great method for their students' education with special needs, but they cannot apply IEP because they do not have enough information about IEP, or they have limits in applying an IEP (Bahar and Yikmis, 2002 [2]; Cetin, 2004 [4]). Metin, Gulec and Sahin (2009) [20] emphasize that there is no one in the school to help them about how to carry out inclusive programs of class masters according to their study. Thus, class masters who know their students best, who can observe and evaluate them are obliged to take the responsibility for arranging and applying the procedures of an IEP. However, the quality and quantity of undergraduate courses on special education taken by class masters is not enough to develop and apply an IEP (Kargin, 2004) [9]. Therefore, questioning the views and ideas of class masters who directly participate in the process of developing and applying an IEP makes a huge contribution to the entire IEP process.

The goal of this study is to put forth the ideas of prospective classroom teachers about development and application of an individualized education program. Below, we seek an answer to those questions in parallel with this purpose. Do prospective teachers

a. have enough information about how to determine the need for an IEP and how to evaluate IEP?

b. feel adequate to develop an Individualized Education Program (writing a goal etc.)?

c. think that they can make educational adaptations for individualized education?

d. have any concerns or suggestions about development and application of an individualized education program?

\section{Method}

This study is based on qualitative research. For qualitative research, we can say that it uses qualitative data gathering methods including observation, interview and document review. It is also possible to say that it enables events and one's perception to be processed successfully in a realistic and integrative way (Yildirim \& Simsek, 2005) [27]. In this study, the method of document review was used. For that purpose, the researcher prepared a questionnaire including few questions, and the researcher put this questionnaire into its final form based on specific expert opinions. The data was collected once all senior students who study class teaching completed this questionnaire. Voluntary students that answered open-ended questions were picked up for an analysis. To analyze the data, two methods - descriptive method and content analysis - were used.

\subsection{Participants}

In one of the universities located in Western Black Sea Region in Turkey, in order to gather information about what senior class teaching students think about IEP and in order to see their progress in preparation of IEP, typical sampling, a sub-brunch of non-probabilistic technique, was adopted (Yildirim \& Simsek, 2006) [21]. This study was conducted with 20 prospective classroom teachers who were in their senior year at the time. The reason why we have preferred senior students is that they are no longer responsible for IEP or courses on special education. Some useful answers given in the questionnaire were taken into consideration in the analysis process. The details of the participants are provided below.

Table 1. The details of the participants

\begin{tabular}{|c|c|c|c|c|c|}
\hline Participant & Sex & Age & Department & Grade & $\begin{array}{c}\text { Received } \\
\text { Inclusive-Special } \\
\text { Education } \\
\text { Training? }\end{array}$ \\
\hline S-1 & Female & 21 & $\begin{array}{c}\text { Classroom } \\
\text { Teaching }\end{array}$ & 4 & Yes \\
\hline S-2 & Female & 22 & $\begin{array}{c}\text { Classroom } \\
\text { Teaching }\end{array}$ & 4 & Yes \\
\hline S-3 & Male & 21 & $\begin{array}{c}\text { Classroom } \\
\text { Teaching }\end{array}$ & 4 & Yes \\
\hline S-4 & Female & 23 & $\begin{array}{c}\text { Classroom } \\
\text { Teaching }\end{array}$ & 4 & Yes \\
\hline S-5 & Male & 22 & $\begin{array}{c}\text { Classroom } \\
\text { Teaching }\end{array}$ & 4 & Yes \\
\hline S-6 & Female & 27 & $\begin{array}{c}\text { Classroom } \\
\text { Teaching }\end{array}$ & 4 & Yes \\
\hline S-7 & Female & 23 & $\begin{array}{c}\text { Classroom } \\
\text { Teaching }\end{array}$ & 4 & Yes \\
\hline S-8 & Female & 21 & $\begin{array}{c}\text { Classroom } \\
\text { Teaching }\end{array}$ & 4 & Yes \\
\hline S-9 & Male & 21 & $\begin{array}{c}\text { Classroom } \\
\text { Teaching }\end{array}$ & 4 & Yes \\
\hline S-10 & Female & 22 & $\begin{array}{c}\text { Classroom } \\
\text { Teaching }\end{array}$ & 4 & Yes \\
\hline S-11 & Female & 22 & $\begin{array}{c}\text { Classroom } \\
\text { Teaching }\end{array}$ & 4 & Yes \\
\hline S-12 & Female & 22 & $\begin{array}{c}\text { Classroom } \\
\text { Teaching }\end{array}$ & 4 & Yes \\
\hline S-13 & Female & 23 & $\begin{array}{c}\text { Classroom } \\
\text { Teaching }\end{array}$ & 4 & Yes \\
\hline S-14 & Male & 21 & $\begin{array}{c}\text { Classroom } \\
\text { Teaching }\end{array}$ & 4 & Yes \\
\hline S-15 & Female & 21 & $\begin{array}{c}\text { Classroom } \\
\text { Teaching }\end{array}$ & 4 & Yes \\
\hline S-16 & Male & 22 & $\begin{array}{c}\text { Classroom } \\
\text { Teaching }\end{array}$ & 4 & Yes \\
\hline S-17 & Female & 21 & $\begin{array}{c}\text { Classroom } \\
\text { Teaching }\end{array}$ & 4 & Yes \\
\hline S-18 & Female & 22 & $\begin{array}{c}\text { Classroom } \\
\text { Teaching }\end{array}$ & 4 & Yes \\
\hline S-19 & Female & 21 & $\begin{array}{c}\text { Classroom } \\
\text { Teaching }\end{array}$ & 4 & Yes \\
\hline S-20 & Male & 24 & $\begin{array}{l}\text { Classroom } \\
\text { Teaching }\end{array}$ & 4 & Yes \\
\hline
\end{tabular}




\subsection{Data Analysis}

The students' answers to open-ended questions were analyzed with a descriptive approach and content analysis. The descriptive analysis is a method of quantitatively describing and interpreting previous data. As there are direct quotations, for a striking representation, the ideas of the participants were pursued as well (Yildirim \& Simsek, 2005 , p. 224) [21]. The main goal of the content analysis is to get the exact terms and relations that can account for the data. The data outlined and interpreted in the descriptive analysis was processed more deeply in the content analysis. In this way, we could find out the exact terms and themes that cannot be distinguished by a descriptive analysis (Yildirim \& Simsek, 2005, s. 227) [21].

\section{Findings}

This part includes an analysis of the answers given by the prospective teachers in the questionnaire with an aim to examine their ideas on development and application of an IEP. With the help of this questionnaire, the findings are presented under four titles according to our sub-goals.

"Is there enough information about how IEP is determined and evaluated?" in line with this sub-goal, a content analysis is given below for the students' answers.

Table 2. Content Analysis for the First Sub-goal.

\begin{tabular}{|c|c|}
\hline $\begin{array}{c}\text { Assessing } \\
\text { the need for an } \\
\text { IEP }\end{array}$ & $\begin{array}{c}\text { Evaluating students by observing (8) } \\
\text { It is hard to identify students' performance (8) } \\
\text { Comparing to other students (6) } \\
\text { Status of given tasks. (4) } \\
\text { By gathering info from parents. (4) }\end{array}$ \\
\hline $\begin{array}{c}\text { Evaluation of } \\
\text { IEP }\end{array}$ & $\begin{array}{c}\text { Class-teacher cannot evaluate by himself (6) } \\
\text { Evaluating with guidance teacher (4) } \\
\text { According to observation results (4) } \\
\text { In an IEP commission (4) } \\
\text { According to IEP goals (2) }\end{array}$ \\
\hline
\end{tabular}

The findings were examined in two categories in parallel with this sub-goal. Some basic ideas are given below:

S-3. "The need for an IEP is assessed by observing the students. An inclusive student succeeds at the end because he behaves in a different way compared to the others. Thereafter, it is important to contact the guidance teacher."

S-16. "By speaking to his parents, we can clearly discover if an IEP is needed or not. An inclusive student's parents have to get in contact with the classroom teacher. Otherwise, it takes time to understand the limits of the student. I really think that it would be difficult for me to discover it."

In the light of the findings, the prospective class teachers mean that it is important to observe students, get information from their parents, and evaluate them based on their performance in the class to understand if an IEP is needed. In addition, these prospective teachers think that it would be challenging to discover the need. These results show parallelism with Cetin's (2004) [4] findings. According to his findings, prospective classroom teachers had difficulty when they had to assess students' performance as well. The commission and guidance teacher emphasized that a class teacher cannot decide on the evaluation phase alone. Also Johns, Crowley and Guetzloe (2002) [13] arrive at the same conclusion that classroom teachers had some difficulty in evaluating in the right way.

"Do they feel adequate to develop an individualized education program (writing a goal etc.)?" The answers are presented below in line with this sub-goal:

Table 3. Content Analysis for the Second Sub-goal

\begin{tabular}{|c|c|}
\hline $\begin{array}{c}\text { Development of } \\
\text { IEP }\end{array}$ & $\begin{array}{c}\text { I am not definitely adequate (14) } \\
\text { Never set/written a goal (10) } \\
\text { Goals are set by a guidance teacher (4) } \\
\text { This process requires team work (2) }\end{array}$ \\
\hline
\end{tabular}

S-1. "As far as I know, guidance teachers set the goals. These goals are student-oriented, and they are acted on throughout the school year. I have not written any goal and I do not feel adequate to do it."

S-9. "I have never written a goal in my life. We have not been taught to do it in any undergraduate courses, and I think it requires team work."

Looking at these findings, it is understood that most of the teachers have difficult moments writing a goal, which is specifically important for development of an IEP. In addition, most of the students express that they have never set a goal before. In line with this result, Johns, Crowley and Guetzloe (2002) [13] indicates that prospective classroom teachers have trouble setting a goal according to students' performance. Additionally, Temel (2002) [24] similarly indicates that classroom teachers are not qualified to achieve inclusion teaching.

"Do they think that they can make educational adaptations for individualized education?" In line with this sub-goal, the content analysis based on students' answer is provided below.

Table 4. Content Analysis for the Third Sub-goal

\begin{tabular}{|c|c|}
\hline \multirow{4}{*}{$\begin{array}{c}\text { Have no idea. So, I can't (12) } \\
\text { There is no enough room for adaptation (8) } \\
\text { IEP }\end{array}$} & $\begin{array}{c}\text { I don't know the special training method (6) } \\
\text { It is not possible, funding is very limited (4) } \\
\text { On-the-job training is important too (2) } \\
\text { I can do if I get support (2) }\end{array}$ \\
\hline
\end{tabular}

S-2. "I don't have any idea about how I can make physical adaptations. As they don't follow the curriculum, they have a program which is totally extracurricular."

S-10. "I personally think that I cannot make an adaptation. Each inclusive student has his own case, so I don't have an idea about most of them."

S-18. "I don't have any idea about how I can do it. It is hard to modify the class environment. It also requires funding."

According to these findings, teachers have no idea about educational adaptations for an IEP. Furthermore, teachers really think that it requires special funding and knowledge. In addition, they doubt that they would get the support they need for it and they emphasize that they do not have enough information on special teaching methods. Izci (2005) [12] 
found out that although teachers want to do some in-class and out-of-class activities, lack of information and ability makes them feel inadequate. Besides, according to Bahar and Yikmis (2002), teachers do have some difficulties in making adaptations and finding materials needed for an IEP process.

"What are their concerns or suggestions about development and application of an IEP?" In line with this sub-goal, the content analysis based on students' answers is provided below.

Table 5. Content Analysis for the Fourth Sub-goal

\begin{tabular}{|c|c|}
\hline \multirow{3}{*}{ Concerns } & I am inadequate (12) \\
& Classes are so crowded (12) \\
& $\begin{array}{c}\text { Opportunities are limited (Material etc.) (10) } \\
\text { Time is not enough to do this (8) } \\
\text { I believe I cannot get support (6) }\end{array}$ \\
\hline \multirow{3}{*}{ Suggestions } & On-the-job training (8) \\
& Special training (6) \\
& Courses on setting and writing goals (2) \\
& Experienced teachers must do this (2) \\
\hline
\end{tabular}

According to these findings, it is obvious that teachers are worried about issues like finance, support and crowded class environment. They also feel inadequate for an IEP process.

S-3. "I don't really think that the school administration can support me, because you know, it is all about money, and this is not totally up to them. In addition, I think we could have a greater number of courses on special education for teaching methods. I often feel really inadequate."

S-7. "I think I am not ready to set a goal. Maybe we can be taught to do it. This is important, as we need to prepare a program. It is possible to set some common goals with a guidance teacher.

S-11. "Classrooms are heavily crowded in Turkey, so how can we help each one of them? Even for non-crowded classes, there is not enough money for this. Could we have financial support from their families? That is the issue here."

According to these findings, teachers are really worried about support, time and class size. Vural's research (2008) [26] indicates that the heads of inclusion class cannot get enough support from the school administration, directorate of national education, counselling and research center, and families. Their concerns about class size show parallelism with Varol's (2010) [25] research. According to Varol, teachers have trouble applying an IEP because of crowded classrooms.

\section{Conclusion and Discussion}

Prospective classroom teachers consider themselves inadequate at distinguishing the need for individualized education, students' performance and at evaluating, setting goals, collaborating with parents and school administration, and making educational adaptations. It is also noted that they think that there will be problems in application of individualized education activities.

In addition, teachers find themselves non-qualified to set a goal. As a result of Spellman's (1989) [23] research on performance of teachers in developing an IEP, most of the teachers have trouble setting the exact goals for the short term and long term for academic, social and physical fields. On the other hand, Lee-Tarver (2006) [17] emphasizes that teachers have a huge role in the IEP process, but they all need much more qualified education for these issues and creating goals as well. According to Izci (2005) [12], classroom teachers are not qualified enough for inclusion teaching. Similarly, Babaoglan and Yilmaz's (2010) [1] research carried out with classroom teachers, teachers remain incapable anyway. Kuyumcu (2011) [16] states that the capacity of students must be evaluated by a teacher, while goals are to be determined and set by a guidance teacher.

Classroom teachers also have problems making educational adaptations for an IEP process. Onder (2007) [21] arrives at a conclusion, as a result of his qualitative research in which 29 class teachers participated, that most of the teachers do not even attempt to make adaptations. Kuyumcu conducted a study in 2011 and states that teachers are inadequate in terms of setting goals and planning educational adaptations.

Teachers also state that they can contribute to an IEP if they could attend more courses on on-the-job training and special education. The existing undergraduate curricula fail to provide prospective teachers with adequate education on these topics (Cetin, 2004 [4]; Izci, 2005 [12]). This problem may be overcome through on-the-job training offered to prospective teachers/teachers at some point in their career. In another study by Metin, Gulec and Sahin (2009) [20], research shows that this kind of on-the-job training affects teachers in a good way. They develop a positive attitude towards, have more information on and gain ability about education. However, it is absolutely important for prospective teachers to receive adequate education before they leave school and before any on-the-job training, which would improve their contribution for the IEP process. Similarly, Gurgur, Kis and Akcamete (2012) conclude that it is important to provide prospective teachers with some practical pre-service opportunities to make them familiar with inclusion applications [10].

Prospective classroom teachers have some concerns about crowded classes and possible problems they would come across while implementing an IEP. In Turkey, the number of inclusive students is increasing year by year while teachers do not get support for special education in general education classes. Therefore, teachers have so many inclusive students, but they are not able to solve all the problems by themselves in the class (Kargin, 2004) [14]. Kuyumcu (2011) [16] concludes that lack of time, which is a result of crowded classrooms, is a huge problem for classroom teachers. Kot, Sönmez, Yıkmış, Çiftçi Tekinarslan (2015) arrive at a similar conclusion, according to their studies with classroom teachers, that teachers do not think institutions or people who need to be involved in the inclusion process cooperate with them in this process. [15]. 


\section{REFERENCES}

[1] Babaoglan, E., Y1lmaz, S. (2010). Sinıf ogretmenlerinin kaynastırma egitimindeki yeterlikleri. Kastamonu Egitim Dergisi, 18 (2), 345-354.

[2] Bahar, M., Yikmis, \& A.,(2002). Kaynastirma siniflarinda calisan ogretmenlerin kaynastirma becerilerini gerceklestirme durumlarinin saptanmasi. Abant Izzet Baysal Universitesi Egitim Fakultesi Dergisi, 2 (3), 85-95.

[3] Cavkaytar, A. (Ed.) (2013). Ozel eğitim. Ankara: Vize Yayınc1lik.

[4] Cetin, C. (2004). Ozel egitim alaninda calismakta olan farkli meslek grubundaki egitimcilerin yasadigi gucluklerin belirlenmesi. Ankara Universitesi Egitim Bilimleri Fakultesi Ozel Egitim Dergisi, 5 (1), 35-46.

[5] Conoley, J.C. ve Conoley, C.W. (2010). Why does collaboration work? Linking positive psychology and collaboration. Journal of Educational and Psychological Consultation, 20, 75-82.

[6] Cuhadar, Y. (2006). İlkogretim okulu 1-5. siniflarda kaynastırma egitimine tabi olan ogrenciler icin bireysellestirilmis egitim programlarının hazırlanması, uygulanmasi, izlenmesi ve degerlendirilmesi ile ilgili olarak sinif ogretmenleri ve yoneticilerin goruslerinin belirlenmesi. Unpublished master's thesis. Zonguldak Karaelmas Universitesi, Zonguldak.

[7] Diken, I. H. (Ed.) (2013). İlköğretimde kaynastirma. Ankara: Pegem Akademi.

[8] Fiscus, E.D., Mandel, C.J. (2002). Developing Individualized Education Programs. (Ed: Prof. Dr. Gonul Akcamete), Istanbul: Seckin Yayıncılık.

[9] Friend, M. ve Cook, L. (2003). Interaction: Collaboration skills for school profesyonals (4st ed.). New York: Allyn and Bacon.

[10] Gurgur, H., Kis, A., ve Akcamete, G. (2012). Kaynastirma oğrencilerine sunulan bireysel destek hizmetlere iliskin oğretmen adaylarının goruslerinin incelenmesi. Illkögretim Online, 11(3), 689-701, 2012.

[11] Gursel, O. (2007). Bireysellestirilmis egitim programı ders notlar1.

[12] Izci, E. (2005). Sinıf ogretmeni adaylarının "ozel egitim" konusundaki yeterlikleri. Elektronik Sosyal Bilimler Dergisi, 4(14), 106-114.

[13] Johns, B. H., Crowley, E. P., \& Guetzloe, E. (2002). Planning the IEP for students with emotional and behavioral disorders. Focus on Exceptional Children, 4(9), 1-13.

[14] Kargin, T. (2004). Kaynastırma: Tanımı, gelisimi ve ilkeler, Ankara Universitesi Egitim Bilimleri Fakultesi Ozel Egitim Dergisi, 5, (2) 1-13.

[15] Kot, M., Sonmez, S., Yikmis, A., Ciftci Tekinarslan, I. (2015). Ilkokul 4. sınıf oğretmenlerinin sosyal bilgiler dersi kapsaminda zihinsel yetersizligi olan kaynastirma oğrencisine yonelik uygulamalari. Abant İzet Baysal Universitesi Egitim Fakultesi Dergisi, Cilt:15 (USBES Ozel Sayisi I), 231-246.

[16] Kuyumcu, Z. (2011). Bireysellestirilmis Egitim Planı (BEP) gelistirilmesi ve uygulanmasi surecinde ogretmenlerin yasadiklari sorunlar ve bu sorunlara yonelik cozum onerileri. Unpublished master's thesis, Ankara Universitesi Egitim Bilimleri Enstitusu, Ankara.

[17] Lee-Tarver, A. (2006). Are individualized education plans a good thing? A survey of teachers' perceptions of the utility of IEPs in regular education settings. Journal of Instructional Psychology, 33(4), 263272.

[18] Lytle, R., \& Bordin, J. (2001). Enhancing the IEP team: Strategies for parents and professionals. Teaching Exceptional Children, 33(5), 40-44.

[19] Milli Egitim Bakanlıgı Ozel Egitim Rehberlik ve Danısma Hizmetleri Genel Mudurlugu (2010). 2009-2010 y1lı ozel egitim kurum ve ogrenci say1lar1. Retrieved 28.10.2015/12:30, fromhttp://orgm.meb.gov.tr/Istatistikler/20092010_GENEL_ SONUC.pdf.

[20] Metin, N., Gulec, H. \& Sahin, C. (2009). Ilkogretim ogretmenlerinin zihinsel engelli cocukların kaynastırılmasına yonelik almis oldukları hizmet ici egitim sonrasında yeterliliklerinin belirlenmesi. I.Ululararas1 Turkiye egitim calısmaları kongresi. Retrieved 21.08.2015/12:30, from oc.eab.org.tr/egtconf/pdfkitap/10.pdf.

[21] Onder, M. (2007). Sinif ogretmenlerinin zihin engelli kaynastirma ogrencileri icin sinif icinde yaptiklari ogretimsel uygulamalarin belirlenmesi. Unpublished master's thesis, Abant İzzet Baysal Universitesi, Bolu.

[22] Ozgur, I. (2001). Ozel egitimde kaynastırma yonteminin boyutları ve sagladig1 yararlar. Cukurova Universitesi Egitim Fakultesi Dergisi, 2 (21), 60-63.

[23] Spellman, R. T. (1989). An investigation of teachers' effectivesness in preparing the individualized educational plan (IEP) as mandated by public law 94-142. Unpublished doctoral dissertation. University of New York, New York.

[24] Temel, Z. F. (2000). Okul oncesi egitimcilerinin engellilerin kaynastırılmasına iliskin gorusleri. Hacettepe Universitesi Egitim Fakultesi Dergisi, 18, 148-155.

[25] Varol, C. (2010). Ilkogretim okullarindaki kaynastirma uygulamalarinin degerlendirilmesi, Ankara.

[26] Vural, M. (2008). Kaynastirma sinifi ogretmenlerinin ogretimin uyarlanmasina iliskin yaptiklari calismalarin belirlenmesi. Unpublished master's thesis, Abant İzzet Baysal Universitesi Sosyal Bilimler Enstitusu, Bolu.

[27] Yildirim, A., \& Simsek, H. (2005). Sosyal Bilimlerde Nitel Arastirma Yontemleri, Ankara: Seckin Yayınc1lık. 